\title{
A substantive conception of work and of the firm - Institutional implications
}

Helena Lopes

Março 2018

WP n. ${ }^{\circ} 2018 / 01$

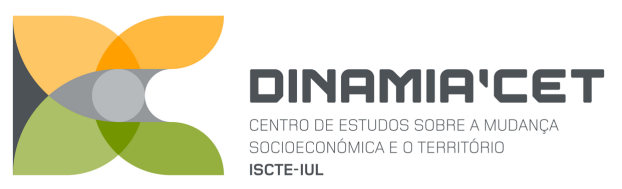

\section{ISCTE IUL}

Instituto Universitário de Lisboa

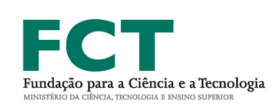




\title{
A substantive conception of work and of the firm - Institutional implications
}

\author{
Helena Lopes* \\ WP n. $\circ$ 2018/01
}

1. Introduction 3

2. The core but neglected features of a substantive conception of work ..........................5

2.1 Work as a meaningful and collective endeavor .......................................................... 5

2.2 The role of sympathy in meaningful and collective work ........................................... 7

2.3 Confrontation to the contemporary evolution of work ............................................... 8

3. Authority as the basis for a substantive theory of the firm ........................................10

3.1 Distinguishing authority from power and defining authority ..................................... 10

3.2 Agency theory - the eviction of authority ............................................................. 12

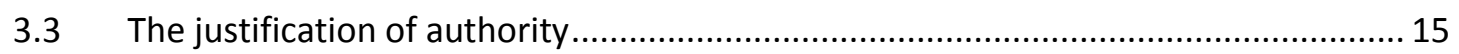

4. Institutional implications of formal and substantive theories of the firm ....................18

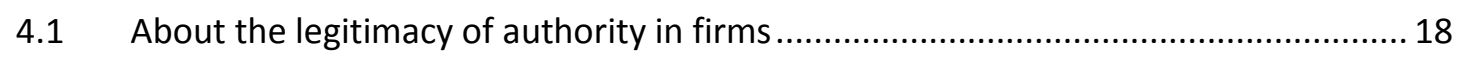

4.2 Legitimating authority: implications for firm governance ......................................... 20

4.3 Digital platform work: firms without authority? ...................................................... 21

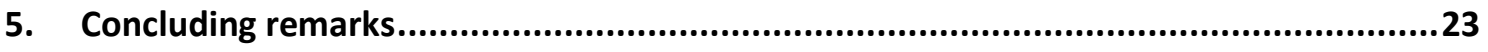

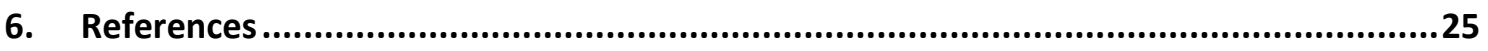




\title{
A substantive conception of work and of the firm - Institutional implications
}

\begin{abstract}
The aims of the paper are to scrutinize the standard economic theory of work and the agency theory of the firm and propose alternative conceptions. By jointly analyzing theories of work and of the firm, maintained separate in the economics literature, we hope to enhance our explanatory and normative power. Firstly, we propose a substantive conception of work defined as a collective endeavor in which interpersonal interactions generate sympathy and explain the emergence of norms of cooperation. Secondly, we propose a substantive conception of the firm based on authority. Drawing on McMahon, we define authority as a collective and normative device whose justification is to facilitate mutually beneficial cooperation among people with divergent aims. We then show that agency theory, which normatively influenced the shareholder governance model, denies that authority is a core attribute of firms. By contrast, an authoritybased theory of the firm normatively requires that firms are governed by reflexive authority, a kind of workplace democracy in which the authoritative directives that guide workers' behavior are collectively determined. We end by showing that authority - but not power - is absent from digital platforms work.
\end{abstract}

Une société se juge au sort qu'elle réserve au travail

Simone Weil

DINÂMIA'CET - IUL, Centro de Estudos sobre a Mudança Socioeconómica e o Território

do Instituto Universitário de Lisboa (ISCTE-IUL)

Sala 2W4 - D | ISCTE-IUL - Av. das Forças Armadas

1649-026 Lisboa, PORTUGAL

Tel. (+351) 210464031 - Extensão 293101 | E-mail: dinamia@iscte-iul.pt | www.dinamiacet.iscte-iul.pt 


\section{INTRODUCTION}

When distinguishing the substantive from the formal approach to economic phenomena, Karl Polanyi contrasts a vision of society in which individuals depend for their living upon their fellows with one in which individuals provide for their living by engaging in atomistic utility calculations. He thereby expressly meant that substantive economics derives from fact while formal economics derives from logic (Polanyi, 1957) and can therefore only inadequately capture the real-world economy.

The aims of the present paper is to scrutinize the most influential mainstream theories of work and of the firm and to point out the substantive features of work and of the firm that their keeping to formalism leads them to dismiss. In short, we characterize the substantive reality of work as a meaningful and collective activity which mobilizes the cognitive as well as the affective and normative dispositions of workers. Likewise, we characterize production in firms as a collective endeavor, i.e. an endeavor which depends on the interpersonal interactions workers enter into, the coordination of which is ensured by authority. Our argument is that the cooperation required by collective production and authority's effectiveness are grounded on the affective/normative dispositions of workers, dispositions downgraded by mainstream economics formalism.

As for work, to paraphrase Pareto (1909), in mainstream economics the workers as real persons may well disappear provided they leave us with their indifference maps - the photograph of their preferences and beliefs. The recent behavioral models of work (Rebitzer and Taylor, 2011), which more realistically acknowledge that workers have social along with selfish dispositions, end up also disposing of the "substantive" worker by treating such dispositions as ("non-standard") preferences. By explicitly remaining within the paradigm of rational choice, behavioral economists constrain themselves to keep the study of interpersonal interactions out of the analysis. The utility calculations are no doubt more complex (Berg and Gingerenzer, 2010) but they do still consist of calculations dealing with own rather than interactive "preferences". Yet, modeling workers as abstract rational agents rather than particular people interacting with one another commits to a modeling strategy in which reality is supplanted by its formal, mathematical, representation, and more precisely by numbers, the elementary particles of mathematical formalism; reality is discarded and replaced by its quantified and quantifiable representation (Supiot, 2015).

In the first part of the paper, we argue that the mainstream theory of work contributed to work being theoretically considered, empirically managed and, moreover, increasingly subjectively experienced by workers, as an individual endeavor driven by quantified objectives. Our analytical aim is to show that the meaning of work and the affective dispositions it involves

\footnotetext{
DINÂMIA'CET - IUL, Centro de Estudos sobre a Mudança Socioeconómica e o Território do Instituto Universitário de Lisboa (ISCTE-IUL)

Sala 2W4 - D | ISCTE-IUL - Av. das Forças Armadas 1649-026 Lisboa, PORTUGAL

Tel. (+351) 210464031 - Extensão 293101 | E-mail: dinamia@iscte-iul.pt | www.dinamiacet.iscte-iul.pt
} 
because of it being a collective endeavor are core elements of "substantive" work that cannot be apprehended in terms of rational calculation. For that purpose, we build on Adam Smith's concept of sympathy as revisited by Sudgen (2005).

As for the firm, within which most work is carried out - it must be beard in mind that it is how workers are managed that defines and designs work - we concentrate on the most influential mainstream theory, namely the agency or "nexus of contracts" theory, based on the rational choice ontological view of agents depicted above. Our analysis of the theory of the firm, in the second part of the paper, focuses on examining one particular issue: "how can it ever be that one has a duty to subject one's will and judgment to those of another?" (Raz, 2006: 1012). Because the source, role and legitimacy of authority in firms are what distinguishes firms from markets (Coase, 1937), they are the analytical and normative core of our inquiry. Agency theory famously contests that there is any authority or power in firms: "the firm (...) has no disciplinary power of fiat, no authority, no disciplinary action any different in the slightest degree from ordinary market contracting between any two people" (Alchian \& Demsetz 1972: 777). In a different strand of literature, Ragan and Zingales (1998) dismiss authority as well but place power at the center of their theory of the firm. Our argument is that authority and power are concepts that need to be thoroughly distinguished because, unlike power, authority raises core theoretical and institutional issues.

The baseline of our argument is that it is authority that actually grounds the collective character of work, and that the cooperation (rather than mere coordination) authority facilitates requires the affective/normative dispositions of workers referred above. To illustrate our argument, we consider digital platform work which, precisely, is not organized as collective endeavor, thus making platform work and platform firms resemble mainstream theories of work and of the firm in which interpersonal relations and authority - though not power - hardly play any role.

Our paper is organized as follows. We begin by briefly recalling the mainstream theory of work and confronting it to the substantive conception of work outlined above (section Two). In section Three we examine the conception - or lack of - of authority in agency theory and build a conception of authority pertinent to work organizations based on McMahon (1994). Section Four elaborates on the normative and institutional issues that follow from an authoritybased conception of the firm. Section Five concludes. 


\section{THE CORE BUT NEGLECTED FEATURES OF A SUBSTANTIVE CONCEPTION OF WORK}

\subsection{Work as a meaningful and collective endeavor}

Mainstream economics portrays work as a source of disutility for workers, an activity engaged in for the sole purpose of having access to income and hence consumption ${ }^{1}$. Work is seen as an instrumental activity in which workers relate with nature rather than with other humans. Nonincidentally, this vision of work was originated by the early marginalists, who restricted the object of economics to the study of the relations between people and nature and who considered that economics would only deal with "the lower elements of human nature" (Edgeworth, 1881), i.e., self-interest and the search for material wealth.

Based on experimental evidence, behavioral economics introduced social preferences, i.e., non-pecuniary motives, into workers' utility functions. For example, experimental findings show that the effort provided by employees is highly dependent on their relationship with the employer (Charness and Kuhn, 2011), thus empirically documenting Akerlof (1982)'s insight that labor contracts are "partial gift exchanges". Likewise, effort levels are higher when subjects are paired with high productivity counterparts and interactions are frequent (Rebitzer and Taylor, 2011). Nevertheless, in behavioral models, social interactions are means by which, or constraints within which, individuals maximize their utility; the individualistic ground of rational choice theory is left untouched. Two major features of substantive work are absent from formal economic models: work is i) a meaningful and ii) a collective activity.

Rosso et al (2010) surveyed the psychological and organizational literature to find out where and how employees actually find meaning in work. Various sources of meaningfulness in work were pinpointed, namely the self, others, the work context and content, and spiritual life. The authors then built an overarching model based on the two dimensions most fundamental to the creation or maintenance of meaningful work. One dimension consists in a continuum that ranges from a desire for agency to a desire for communion, which captures the extent to which the source of meaning lies within the individual or in a collective group, while the other dimension consists in a continuum ranging from self-directed to other-directed action (Lopes, 2018). The relevance of the model is supported by empirical tests that highlight "the importance of reciprocal dynamics between individuals and groups [... whereby] the individual works to benefit the self and the collective, and the fruits of this work enhance both self and collective" (Steger et al, 2012: 324). Thus, what is critical in the meaning of work is that it must

\footnotetext{
${ }^{1}$ Institutional economics have always challenged this view. For more recent institutional references, see Spencer (2009), Lopes (2011), Lopes (2018).

DINÂMIA'CET - IUL, Centro de Estudos sobre a Mudança Socioeconómica e o Território do Instituto Universitário de Lisboa (ISCTE-IUL) 
simultaneously benefit society and possess an intrinsic value for the worker himself. To sum up, empirical evidence suggests that substantive work is at least as much a matter of judgement on the usefulness for others and oneself of the work performed than a calculation of whether the wage compensates for its disutility.

Coase (1937: 393)'s definition of the firm provides a concise statement of the second feature of substantive work: "A firm consists of the system of relationships which comes into existence when the direction of resources is dependent on an entrepreneur".

The "system of relationships", which in the case of firms includes direction, is what we call a collective of work. A wide list of reasons are advanced in the economic literature to prove the superior efficiency of collective and directed work over isolated work. Directed work lessens transactions costs (Coase, 1937; Williamson, 1980, 1975); team production generates the unique productivity gains that distinguish firms from markets (Alchian and Demsetz, 1972); collective work allows building complementarities through specialization, meaning that two persons can together create more value that they can going their separate way, and it gets employees make firm-specific investments (Rajan and Zingales, 1998; Williamson, 1975); according to Frank Knight (quoted by Coase, 1937), directed work allows facing uncertainty, defined by the necessity of acting upon judgement rather than knowledge when having to decide what and how to do.

Because if there is to be order in the system, Coase (1937) emphasizes that the contracts required are employment contracts whereby employees agree to obey the directions of an entrepreneur within certain limits. When uncertainty is present, the internal organization of the productive process is not a technical issue: it requires centralization of decisions and judgment ${ }^{2}$ on the part of managers.

Behavioral economists (Fehr and Gintis, 2007) acknowledge that the employment relationship is irreducibly incomplete, which makes the exchange of work be not a market but a "social exchange", one that involves a series of interactions that generate informal, unspecified, obligations. The employment relationship thereby tends to evolve over time into trusting and mutual commitments. But experimental evidence shows that the sustainability of cooperation is nonetheless conditional on punishment options or other institutional devices (Charness and Kuhn, 2011). Working in firms actually involves entering into a large set of distinct relationships, not only with peers but also with supervisors. In work organizations, employees are members of many groups since they have to work/coordinate together to generate products or services. Empirical research shows that interpersonal interactions at work influence the

\footnotetext{
2 The frequent use of the term "judgement" by early economists contrasts with its quasi absence in contemporary mainstream economics.
}

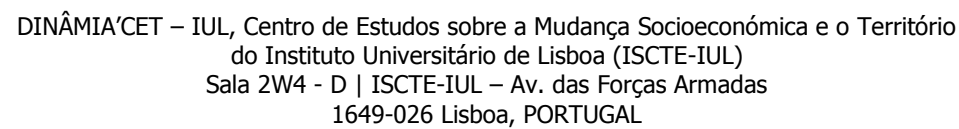


meaning of work; membership in and connection to work groups provide individuals with meaningfulness by making them experience a sense of belonging (Kluver at al, 2014; Rosso et al, 2010). We shall see below that this sense of belonging and the sustainability of cooperation are promoted by the institution of authority.

\subsection{The role of sympathy in meaningful and collective work}

Substantive work is thus characterized by several kinds of interpersonal interactions, i.e., interactions between people who interact as particular individuals. By contrast, standard economics models are populated by abstract, i.e. impersonal, isolated rational agents characterized by their cognitive abilities. As referred, behavioral economics now relaxes some assumptions and explores the way "socially oriented" motivations affect economically relevant behaviors; such motivations are represented as properties of preferences and, consistent with rational theory framework, each individual concentrates on satisfying his/her own preferences; the way the latter are formed is disregarded. Considering this framework inadequate to give account of core features of substantive work, we follow Sugden (2005: 53, his italics) in going "outside the paradigm of rational choice - indeed, outside the paradigm of choice. My concern is with the processes by which the affections of different individuals interact with one another".

Adopting Sugden's perspective (itself inspired by Adam Smith's concept of sympathy in The theory of Moral Sentiments), our claim is that the interpersonal relations in which workers inescapably enter when working together generate affective states that help sustain norms of cooperation. Sugden emphasizes that affective states are not preferences, i.e. objective options apt to be compared to one another, but instead subjective experiences of the world. Being neither preferences nor beliefs, affective states do not fit into the ontological framework of rational choice theory. He also highlights the fact that Smith's concept of sympathy was meant to explain complex social phenomena, namely the practices of morality, rather than to describe human psychology. For Smith, social phenomena are to be understood as emergent properties of interactions between individuals. His basic psychological assumption is that individuals have a capacity to feel imaginatively the experience of others and so to share their pleasures and pains; this leads to a "correspondence of sentiments" between people ${ }^{3}$. This correspondence of affective states - or "emotional contagion" - is in turn the basis for judgements of approval or disapproval of others' and own actions. The whole process thus involves cognitive elements as well as affective ones and, importantly, it is fundamentally unconscious and involuntary, being thereby hardly apt to any kind of calculation. The paradigm

\footnotetext{
${ }^{3}$ Adam Smith's psychological assumptions had been fully confirmed by contemporary neuroscience and psychology, which label them "empathy" rather than "sympathy" (Zaki et al, 2012). 
of choice fails to capture the relational dimension of sympathy. Sympathy leads people to adapt their sentiments to those of others and therefore to subscribe to the same behavioral norms (if the sentiments and respective actions are judged normatively appropriate).

Therefore, through recurrent interactions, as in the case of workers facing common problems in pursuit of common goals, the members of the collective tend to converge on common normative behaviors. (Of course, processes of affective dissonance and corresponding judgments of disapproval may lead to severe disruptive events and breaks of cooperation.) Smith's concept of sympathy hence provides a powerful explanation of i) why the meaningfulness of work is so closely related with its usefulness for others and its relational and collective character and ii) why collectives of work tend to cooperate under authority (see below).

Importantly, Smith's insights are now documented by organizational scholars, who also came to acknowledge that cognitive processes do not give a complete picture of shared social processes; namely it is shown that emotional contagion greatly affect individual-level attitudes as well as group processes. Specifically, the positive emotional contagion group members experience leads to greater cooperativeness largely because they are associated to social judgements and behavior (Barsade, 2002).

\subsection{Confrontation to the contemporary evolution of work}

Now, in this regard, nowadays' real world of work raises severe concerns. Work is everywhere subject to a process of quantification (also related to the financialization process (Cushen and Thompson, 2016)), marked by practices like individualized and quantified performance targets, quantified appraisal systems and rankings, rising wage differentials, unobstructive monitoring like standardization of practices, extensive reporting procedures, etc. These practices definitely show that it is the outcomes of work rather than the workers as persons that are the primary focus of management. The human activity of work is being translated into numbers of products, clients, reports, etc., in a prodigious endeavor to transcribe work into an abstraction intelligible and suitable for financial analysis. This quantification of work is part of the "governance by numbers" process (Supiot, 2015) ${ }^{4}$ that progressively invades all work organizations, a kind of governance supposed to be axiologically neutral - work being assessed on the basis of objective criteria - but which actually contributes to overlook the subjective and collective experience of work. The human dimension of work and workers is neglected, empathic concern is

\footnotetext{
${ }^{4}$ For Supiot (2015), the "manage ment by objectives" that initially appeared in firms developed into what he terms "governance by numbers", a mode of governance that is now permeating all levels of human life - the individual, the firm, the state and international relations.
} 
progressively disappearing from workplaces and managers do not - have to - feel accountable for the socio-psychological well-being of their subordinates ${ }^{5}$. Workers are being made invisible.

The fact that the prevailing management rhetoric solicits the cognitive and affective investment of workers in the pursuit of and identification with organizational goals makes this factual trend of quantification of work especially paradoxical. Indeed, good managers are well aware that the workers' loyalty and cooperative spirit are more efficiently fostered by granting them greater decision-making scope than submitting them to technical prescriptions and quantified control. A solution has been found to solve this paradox: workers are (frequently though not always) involved in the setting of the objectives they are required to achieve and for which they are made accountable (Supiot, 2015). These objectives are quantified but no longer look like prescriptions decided by some external instance; rather the workers are supposed to carry out their objectives driven by their own will and self-control. They feel like acting "freely" rather than under someone's command, which makes them give their best.

There is a problem with this solution though: it affects the workers' mental health. Indeed, on one hand, the workers are supposed to work driven by their intrinsic/autonomous motivation to do the work they agreed to perform. But, on another hand, they have to respect deadlines and directives and are under pressured evaluation associated to sanctions. That is, being led to agree with their work objectives put them in a perverse situation: the autonomy this is supposed to give them is false; in fact, their choice and opportunities for self-direction are limited and their feelings un-respected - their behavior is externally/extrinsically regulated and controlled (Deci et al, 2017). These management practices - a focus on quantification and false autonomy - have resulted in a significant intensification of work, burnout, emotional exhaustion, dissolution of collective solidarities, depersonalization and deterioration of work relations, feelings of isolation and of culpability when performance targets are not met (Le Gall, 2011). In the last decades, the workers' vulnerability and psycho-social disorders have intensified considerably (Netterstrom et al, 2008; Theorell et al., 2015). Workers face a tension between the need for meaningful work, which includes the feeling of usefully contributing to and being part of a collective, and the pressure to enter into a competitive game where they are often compelled to behave selfishly to meet their quantified targets.

What is presently going on in workplaces is what Brons (2017) denounces as "cultural psychopathy", namely the acceptance or even approval by some culture or social group that the individual lack of empathy (sympathy in Smith's terms) is normal rather than deviant; it is the

\footnotetext{
${ }^{5}$ This is an oversimplification of reality. Of course, many managers and employers over the world do feel concerned with their employees (in Nordic countries, this concern is part of management functions). Our intention here is to capture the prevailing trends in the management of work, at the cost of not doing justice to "good practices".
} 
normalization of individual psychopathy ${ }^{6}$. Brons (2017) consideres that if mainstream economics succeeds in empirically promoting homo economicus, whom he (rightly) associates with the picture of a psychopath, then it promotes psychopathy. The substitution of governing numbers for managing people may well be the most emblematic instance of such promotion.

\section{AUTHORITY AS THE BASIS FOR A SUBSTANTIVE THEORY OF THE FIRM}

\subsection{Distinguishing authority from power and defining authority}

Espousing Coase's view, we see authority as what distinguishes firms from markets. Given the considerable underlying normative and institutional challenges, authority and power need to be thoroughly distinguished.

The most important distinctive trait is that authority involves a right to get something done while power is the ability to get it done, regardless of opposition. "As a right, authority depends on acceptance (or recognition, acknowledgment, consent, etc.) of that right: authority is created by acceptance. Power, on the other hand, is objective fact" (Brons, 2017: 38; his italics). To have power over someone means to be able to have him/her do something while to have authority means having one's judgment accepted.

Bowles' definition of power and Simon's definition of authority are in the same line. "For B to have power over A, it is sufficient that, by imposing or threatening to impose sanctions on A, B is capable of affecting A's actions in ways that advance B's interests, while A lacks this capacity with respect to B" (Bowles 2004:345). By contrast, "B [the boss] exercises authority over W [the worker] if W permits B to select x [the task to be performed]" (Simon 1951: 294; our italics). Power and authority are asymmetrical relationships in which a person has influence on another. But, unlike power, the exercise of authority does not involve the threat or use of sanctions; rather, employers have discretion regarding which task to select to the extent that workers permit them to do so. The objective fact of obedience depends on the existence of subjective acquiescence; authority is a form of directive power, but a power without coercion ${ }^{7}$. Power is coercive but one cannot be coerced to think something, only to do something and pretend one accepts it. Which entails, as lengthily developed by Weber (1922),

\footnotetext{
${ }^{6}$ For Brons (2017) mainstream economics is a major cause of this circumstance because it never "returns from abstraction to the real world" and believes that efficiency requires unbridled competition, thus "abstracting away cooperation, mutual support and everything else that makes us human" (Brons, 2017:51).

${ }^{7}$ We are obviously aware that, beyond authority, power under the form of coercion does pervade work environments.
} 
that authority, contrary to power, involves a claim to legitimacy; the right to exercise authority must be justified to subordinates.

It is worth highlighting that authority is a universal phenomenon; it pervades all human societies and is accepted since the first Greek philosophers to be at the basis of social order. Real-world and laboratory evidence show that authorities are spontaneously empowered as soon as individuals gather or/and whenever a problem arises (Tyler \& Lind 1992). This signals a spontaneous human propensity towards structure and authority. Authority is also a universal trait of firms (Arrow 1974); it is impossible in an organization to coerce or persuade all workers to comply with directives; compliance is (at least partly) voluntary.

Simon (1951) acknowledges that the effectiveness of authority is conferred by those whose actions are directed, but he takes obedience for granted provided the task falls within a "zone of acceptance". There is no account in the economic literature of why employees accept subordination to authority and comply with directives or accept the quantified objectives they are assigned ${ }^{8}$. We then resorted to the contributions of political science and build our concept of authority on McMahon (1994), who applies Raz (1986)'s authoritative analysis of political authority to the managerial sphere.

McMahon (1994) explains authority by the following cognitive mechanism: subordinates take the authority's directives as preemptive reasons for acting, i.e. the authority's directive to do $\mathrm{X}$ is not considered alongside the other reasons to do $\mathrm{X}$ but instead preempts these reasons. Accepting authority involves excluding from consideration certain reasons for action, including one's own reasons. Individuals as subordinates suspend their judgments, which are replaced, that is, preempted, by the authority's directive. For McMahon, as for Arrow (1974), the threat of being fired, the fact that one is paid, or the legal duty to comply with the employer's orders do not provide the sort of reason for obedience that can justify the authority of managers. There are reasons for complying with managerial directives that are independent of the threats managers can make and are prior to any legal power a given authority may possess.

McMahon (1994) distinguishes three kinds of authority9. "E-authority", or authority of Expertise, derives from the informational or knowledge advantage of a party over another. An E-authority is someone who is thought to be an expert in some field; E-authority is not subordinating because there is the belief that the person in authority does know more. An E-

\footnotetext{
${ }^{8}$ Even transaction costs theories of the firm (not addressed here for matter of space), which, following Coase and Simon, recognize that authority plays a crucial role in the functioning of firms, very insufficiently distinguish authority from power.

${ }^{9}$ McMahon makes it clear that his conception of authority, notwithstanding many points of convergence, substantially differs from that of Weber.
}

\footnotetext{
DINÂMIA'CET - IUL, Centro de Estudos sobre a Mudança Socioeconómica e o Território do Instituto Universitário de Lisboa (ISCTE-IUL) 
authority persuades us to believe that the directive is the right thing to do and we follow our own will and judgment in complying with it.

"P-authority" derives from a Promise to obey; if one promises to obey someone's directive, the promise becomes a preemptive reason to comply with the directive, independently of our reasons and judgments at the moment of complying. Hence, P-authority is subordinating authority. Engaging in an employment contract may be considered a typical instance of Pauthority since it implies having a duty to yield obedience to all reasonable instructions of the employer. By promising, we impose on ourselves obligations toward others that we did not have before.

"C-authority" derives from the fact that management facilitates mutually beneficial Cooperation among individuals with divergent aims and beliefs. C-authority involves complying with directives, i.e. considering them as preemptive reasons for acting, because it benefits each and all members of the collective. When individuals think they can produce a state of affairs better for everyone, including themselves, by acting together, they accept subordination and obey directives. It must be emphasized that whereas E- and P- authority are bilateral relationships, C-authority is collective in character. Though E- and P- authority also permeate work environments, C-authority - authority hereafter - is the form of authority most prevalent in work organizations. In fact, for most social scientists, authority is a collective phenomenon: "the very nature of authority is the transfer of power from many to one" (Tyler \& Lind 1992: 164). C-authority demands further examination because its justification is much more problematic than that of the two other forms of authority. Before examining the justification/legitimacy issue of authority, it must be pointed out that authority is ostensibly dismissed from mainstream theories of the firm.

\subsection{Agency theory - the eviction of authority}

Notwithstanding their explicit denial of authority in firms (see quote in the introduction), Alchian \& Demsetz (1972)'s theory of the firm as team production leads them to recognize the need for a "centralized contractual agent" because team production creates a social dilemma every team member has an incentive to shirk on his/her productive efforts. To reduce shirking, team members agree upon being supervised by a monitor who checks free riding and adjusts rewards to each member's actual effort. This is a Hobbesian-type solution in which there is mutual consent to submit to monitoring because this is in the interest of each and all - but authority is inexplicably explicitly kept out of the picture: "The relation of each team member to the owner of the firm is simply a contract. [...] The employee 'orders' the owner to pay him money in the same sense that the employer directs the team member to perform certain acts. [...]

\footnotetext{
DINÂMIA'CET - IUL, Centro de Estudos sobre a Mudança Socioeconómica e o Território

do Instituto Universitário de Lisboa (ISCTE-IUL)

Sala 2W4 - D | ISCTE-IUL - Av. das Forças Armadas

1649-026 Lisboa, PORTUGAL

Tel. (+351) 210464031 - Extensão 293101 | E-mail: dinamia@iscte-iul.pt | www.dinamiacet.iscte-iul.pt
} 
'Authoritarian' or 'fiat' attributes [are not] relevant to the conception of the firm or its efficiency" (Alchian \& Demsetz 1972: 783). Employment contracts, like relationships between monitors and employees, are freely bargained and symmetrical, just like any commercial contract.

Jensen \& Meckling (1976) went further in this "horizontalization" of the firm by arguing that there is no need for a centralized agent - in their view, team production is the exception rather than the rule. The firm is formally reducible to a nexus of contracts. The building block of agency theory is a particular social interaction, namely the principal-agent relationship defined "as a contract under which one person (the principal(s)) engages another person (the agent) to perform some service on their behalf which involves delegating some decision-making authority to the agent" (Jensen and Meckling 1976: 308) ${ }^{10}$. There is in this definition a truly puzzling denial of the phenomenon of authority. Not only do Jensen \& Meckling negate the need for any authority, or "centralized agent", but they invert the authority relationship: agents are to act on principals' behalf but it is principals who delegate decisionmaking authority to agents. This is exactly the reverse of Simon's definition, and it leads to seeing principals as being at the mercy of agents' opportunism (because of the scope of discretion they are given) rather than seeing agents at the mercy of principals' power. In fact, the word "authority" is used to mean "discretion".

Agency theory views workers as rational agents for whom effort generates disutility and who consequently behave opportunistically at the expense of principals. This is why the notion of "agency costs" - i.e. monitoring costs and incentive contracts - is the core theoretical element of agency theory, which would disintegrate without it. It must be noted that the use of "agency" by agency theory stands in sharp contrast with the notion of agency as first introduced by law scholars. In law, the agency relationship presupposes that "the alleged agent and principal have met each other face to face, or have talked on the telephone, or have otherwise communicated in a specific, individualized way" (Clark, 1985: 85). Furthermore, in law, the notion of an agent is one who acts for another even at a cost to him/herself; the laws of agency imposing a specific duty of loyalty on the agent (Duska, 1992). Mainstream economists adopted the notion of agency but removed the attribute of loyalty/commitment it is endowed with in law, to make it consistent with i) the ontology of rational choice theory and ii) their conception of firms as composed of contractual relationships substantially similar to market relations.

\footnotetext{
${ }^{10}$ Jensen and Meckling (1976) is the third most cited paper in economics of those published since 1970 (Kim et al. 2006). When writing the paper, the authors were thinking of shareholders as principals and chief executives as agents, but the terms generalized since to all kinds of principal-agent relationships.
}

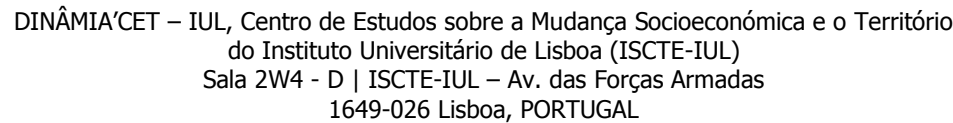


The presumption seems to be that obedience/subordination - note that the terms are never mentioned in agency papers - are exchanged against rewards: principals pay to be obeyed; obedience to authority is a matter of calculations. But social psychologists emphasize that outcomes incentives do not secure obedience and compliance (Tyler \& Lind 1992: 161,166). Besides, McMahon (1994: 29) highlights that "someone who does what A says because he expects a reward for doing so is not in a relation of subordination to A. But someone who complies with an authoritative directive is in a relation of subordination to the person issuing it". In the latter case, contrary to the former, the person has taken A's directive as preemptive, i.e., the directive has replaced the person's reasons to act.

Aghion \& Tirole (1997) were the first to expressly address authority within agency theory. Their paper deals with how to better allocate decision rights between a principal and an agent, depending on informational advantages and costs. It is E-authority which is at stake. (Like in Jensen and Meckling, "authority" is used to mean "discretion"). As pointed out, Eauthority is not subordinating authority; roughly, it does not involve B acting on A's reasons because A and B came to agree on the right action to take, given the information setting. Similarly, in Bolton \& Dewatripont's (2013) survey, the reviewed models mostly examine instances of E-authority. The last pages of the survey do address "interpersonal authority"; compliance is recognized to be problematic because agents suspect that principals may exploit them. The agents' obedience and conformity with authority directives are ultimately explained by the principal's threat to dissolve the relationship (see, e.g. Van den Steen 2010), which means that authority/subordination is analytically transformed into a power relationship. Obedience is ultimately obtained through calculations or sanctions.

As referred, P-Authority may be seen as being comprised in the employment relationship. But for mainstream economists, this does not by itself make it enforceable because individuals are seen as always likely to renege on their commitments. Hart (2002) maintains that although firms would have difficulty surviving in a norm-less society, it cannot be assumed that employers or employees are to be trusted to keep their word. He associates keeping one's promise to "irrational" behavior (p. 1705) and explicitly states that self-interested parties are not trustworthy because there will always be an incentive to break a promise (p. 1703). Individual interest calculations simply do not submit to any categorical imperative imposed by law - a major feature of the rationale of the Law and Economics literature (Supiot, 2015).

Importantly, two other mainstream theories also expel authority from the theory of the firm but, acknowledging that some kind of hierarchy is needed in a world of incomplete contracts, they resort to power. For property rights theory, ownership of physical assets confers the power to exercise control over human assets: "The reason that an employee is (...)

\footnotetext{
DINÂMIA'CET - IUL, Centro de Estudos sobre a Mudança Socioeconómica e o Território do Instituto Universitário de Lisboa (ISCTE-IUL)

Sala 2W4 - D | ISCTE-IUL - Av. das Forças Armadas 1649-026 Lisboa, PORTUGAL

Tel. (+351) 210464031 - Extensão 293101 | E-mail: dinamia@iscte-iul.pt | www.dinamiacet.iscte-iul.pt
} 
responsive to what the employer wants $(\ldots)$ is that the employer can deprive the employee of the assets he works with" (Hart, 1989: 1771). It is fear rather than consent, or freely negotiated contracts like in agency theory, which grants obedience. Rajan and Zingales (1998), contesting property rights theory on the grounds that human assets, rather than solely physical assets, are the main source of value of the firm, claim that ownership is not the only source of power ${ }^{11}$. Firms can also exercise power by regulating the access to their critical non-physical resources. The theoretical difference with property rights theory is that workers are considered part of the firm, which is conceived of as a political entity that has to sensibly utilize power to reach its goals. In fact, these two theories are claiming that, contrary to agency theory's assertions, the sources of an employer's authority cannot be explained by contracts only; in their view, power (unilateral and coercive) is needed.

\subsection{The justification of authority}

By contrast, we assume, like Coase, Simon, Arrow and others, that authority, a form of noncoercive power is also required for the functioning of firms. We then turn to the crucial question raised by authority: "how can it ever be that one has a duty to subject one's will and judgment to those of another?" (Raz, 2006: 1012).

According to McMahon (1994), inspired by Raz, what justifies managerial authority (Cauthority), i.e., the reason why subordinates comply with directives, is that complying is better, from the moral standpoint of each member, than the state of affairs that would obtain were directives disregarded. By facilitating cooperation, authority allows for Pareto-improving outcomes. Subordinates suspend their judgment and follow instead the authority's directives because they believe this advances their own and the collective aims. Although authoritative directives preempt own judgment, ultimate self-reliance is preserved for it is own judgment that recognizes authority ( $\operatorname{Raz} 2006$ ). That is, those under authority do not surrender their judgment; they just suspend it.

For McMahon (1994), C-authority supports cooperation i) because, by making the cooperative solution salient, it solves coordination problems, and ii) it discourages workers to free-ride because workers expect others to cooperate as well. But, as Arrow (1974) points out, convergent expectations - the fact that everyone expects others to obey because it is instrumentally beneficial to everyone - do not suffice to explain obedience. McMahon's answer to this objection is that the effectiveness of authority is explained by collective rationality, which he sees as consubstantially associated to C-authority; only collective rationality can fully

11 Although heavily quoting Coase (1937), Rajan and Zingales entirely dismiss the fact that Coase distinguished power from authority, thus being very unfaithful to their mentor.

\footnotetext{
DINÂMIA'CET - IUL, Centro de Estudos sobre a Mudança Socioeconómica e o Território

do Instituto Universitário de Lisboa (ISCTE-IUL)

Sala 2W4 - D | ISCTE-IUL - Av. das Forças Armadas

1649-026 Lisboa, PORTUGAL

Tel. (+351) 210464031 - Extensão 293101 | E-mail: dinamia@iscte-iul.pt | www.dinamiacet.iscte-iul.pt
} 
realize the benefits of cooperation. It is collective rationality that makes subordinates want to achieve mutually beneficial outcomes.

We agree that to understand $\mathrm{C}$-authority and the renunciation of free riding (without resorting to coercive power), we need to give up the assumption of individual rationality but, for the purpose of explaining authority, McMahon's appeal to collective rationality raises, in our view, three serious issues. First, collective rationality, like team reasoning and other models of "we" notions in the game theory and social ontology literature (see Sugden (2015) for references), aim at demonstrating that a group of people can intentionally pursue their mutual advantage because they can reason "as teams", or, more rigorously, as team members, which makes norms of cooperation emerge and reproduce themselves spontaneously. The team reasoner considers the strategies that can be chosen by the players in combination, assesses them in terms of the consequences for them together, finds the strategy that is in the collective interest and contributes his/her part. Sugden (2015:154) criticizes these classical game theory's models for being instrumentally rational, which is precisely what he finds problematic. McMahon's account of authority also ultimately comes down to a relatively straightforward cost-benefit analysis (Oosterhout, 2007). Although its cooperation-facilitating property no doubt supports authority, the efficiency of authority cannot explain why it is obeyed - only that it should be obeyed.

What must be explained in the first instance are the processes by which someone may feel part of a team or may want to pursue the collective rather than own interest. This is the second issue. In other words, what can make people be sure that enough others will make their part of the cooperative endeavor? We argued above that explaining this is beyond rational choice's capacity, i.e., reason alone cannot spell it out. This is where Smith's theory of sympathy enters. Correspondence of sentiments may give people the consciousness that other people share the motivation of doing their part, and that they approve this behavior in you. Wanting mutual benefit and believing that others will cooperate rather than free ride may be explained by correspondence of sentiments (emotional contagion), which is induced by interpersonal interaction (Sugden 2005: 73, 74). The fact that work is a collective endeavor combined with the vital human ability of sympathy is what accounts for the source of Cauthority, i.e., for the convergence on common normative - cooperative - behavioral norms.

The third issue is that existing models of collective rationality or team reasoning analytically assume that there is only horizontality between agents. Yet, what is at hand here is to explain authority, a phenomenon in which people subject their will and judgment to those of another. This leads us to a matter not addressed so far: the fact that authority involves "verticality". In authority, something higher than the strictly individual is at stake; authority

\footnotetext{
DINÂMIA'CET - IUL, Centro de Estudos sobre a Mudança Socioeconómica e o Território do Instituto Universitário de Lisboa (ISCTE-IUL)

Sala 2W4 - D | ISCTE-IUL - Av. das Forças Armadas 1649-026 Lisboa, PORTUGAL 
embeds a vertical relationship. The aim of those in charge of authority in firms is not trying to maximize each member's individual interest but instead to pursue the goals of the organization, which can be seen as a kind of " $n+1$ "-level common interest. Supiot (2015) emphasizes that individual interests (the "horizontal component" of mutually beneficial cooperation) must not be seen as in opposition to the common interest (its "vertical" component); rather, both must be seen as two different but complementary positions because the horizontal adjustment between individual interests depends on the stability of the vertical common interest. What is at stake in this regard in firms is the relationship between the individual and the collective of work. And Supiot insightfully adds (like Frank Knight decades ago) that the common interest is not a matter of calculation but one of judgement. This is so because the passage from the horizontal/individual to the vertical/collective is the hallmark of the political - which is constitutively normative. The grounding of deference to authority ultimately entails a normative rather than exclusively calculative facet ${ }^{12}$.

To be fair, authority is at the root of enormously inhumane phenomena. Psychological evidence shows that those in authority are tempted to be exploitative and do often take the opportunity to exploit subordinates for their own benefit (Tyler \& Lind 1992). No doubt that organizational order can be established with the use of force and power. But if we are to avoid violence and the strength of the strongest, appropriate, i.e. legitimate, institutional arrangements are required. Correspondence of sentiments may explain renouncing to free riding - having some assurance that at least enough others will renounce too - but it is insufficient alone to establish and sustain mutually beneficial cooperation, as documented by experimental evidence (Fehr and Gintis, 2007).

\footnotetext{
12 For Arrow (1974: 64), authority transcends calculations: "To some extent, no doubt, the acceptance of all authority is a transfer from the supreme authority of religious belief". For Simone Weil (1949: 10-11), in turn, "those who command, obey in their turn, and the whole hierarchy should have its face set in the direction of a goal whose importance can be felt by all".
}

\author{
DINÂMIA'CET - IUL, Centro de Estudos sobre a Mudança Socioeconómica e o Território \\ do Instituto Universitário de Lisboa (ISCTE-IUL) \\ Sala 2W4 - D | ISCTE-IUL - Av. das Forças Armadas \\ 1649-026 Lisboa, PORTUGAL \\ Tel. (+351) 210464031 - Extensão 293101 | E-mail: dinamia@iscte-iul.pt | www.dinamiacet.iscte-iul.pt
}




\section{INSTITUTIONAL IMPLICATIONS OF FORMAL AND SUBSTANTIVE THEORIES OF THE FIRM}

The aim of the previous sections was to provide a substantive conception of work and the firm by examining its foundational cognitive and normative mechanisms. It was emphasized that meaningful work and authority effectiveness call for cognitive, affective and normative dispositions that break with the abilities with which rational agents are endowed in the formal approach to economics. Our aim below is to point out the institutional implications that stem from formal versus substantive theories of the firm.

\subsection{About the legitimacy of authority in firms}

When looking for a theory of the firm on which to ground corporate law, it was Jensen \& Meckling (1976)'s finance-based approach that was adopted and agency theory soon became the dominant paradigm in corporate scholarship (Bodie, 2012; Armour, 2005). Because shareholders are claimed to bear the greatest investment risk - the other input providers being protected by their respective contracts - they should be given control over governance rights, i.e., over the board of directors (management). Thanks to its academic influence, agency theory pervaded business schools, being taught to millions of students and executives around the world. It thus became a powerful normative management model (Goshal, 2005). The primary purpose of corporate governance became that of assuring that managers/directors act in the interest of shareholders: "both boardrooms and courts have taken the normative call for shareholder value maximization increasingly at heart" (Bodie 2012: 1033) ${ }^{13}$.

The fact that agency theory "provided a quasi-scientific rationale for deinstitutionalizing the corporation" (Davis, 2016: 509) may explain its extensive influence. Which means that the formal economic approach diffused and powerfully influenced the way firms are - to be - governed. But the "shareholder primacy" governance model is increasingly criticized for focusing on financial transactions and leaving corporate law disconnected from the strategic and operating management of the firm (Bodie 2017; Greenfield 1998), being thus denounced for hindering innovation and the long-term sustainability of many firms (Marsden, 2016).

Whilst the institutional/normative influence of agency theory disseminated unproblematically, probably because, being theoretically grounded on voluntary contracting and private ownership, it was supposed axiologically neutral, the institutional implications that may

\footnotetext{
${ }^{13}$ Although they recognize that firms have responsibilities to other stakeholders, the OECD Principles of Corporate Governance, revised in 2015 , still state that this should be the primary objective of firms.

DINÂMIA'CET - IUL, Centro de Estudos sobre a Mudança Socioeconómica e o Território

do Instituto Universitário de Lisboa (ISCTE-IUL)

Sala 2W4 - D | ISCTE-IUL - Av. das Forças Armadas

1649-026 Lisboa, PORTUGAL

Tel. (+351) 210464031 - Extensão 293101 | E-mail: dinamia@iscte-iul.pt | www.dinamiacet.iscte-iul.pt
} 
be derived from the authority-based theory of the firm are certainly much more contentious. According to empirical evidence, the legitimacy of authority is crucial for its effectiveness and is grounded on both substantive and procedural considerations. Specifically, it is judgments about procedural justice, i.e., about whether decision-making procedures are perceived to be fair, that prove to be the strongest and most consistent predictor of compliance with authority's directives (Crawshaw et al. 2013). For example, the opportunity to voice one's view about assigned objectives results in higher rated acceptance and better performance (Tyler and Lind 1992). The question is then: How can the duty one has to subject one's will to that of another be legitimated?

Firstly, if authority is justified because it facilitates that the members of a collective endeavor do better by complying, these members may legitimately demand to be able to check whether a mutually beneficial outcome is actually obtained. This allows operationalizing the idea that authority must be justified to those whose actions are directed, that is, ensuring the instrumentalist, or substantive, justification of authority (Christiano 2004), a justification based on the value of the outcomes of the exercise of authority.

Secondly, since authority, as conceived here, is not solely instrumental but also a normative device that enables people who disagree about how their common affairs should be conducted to nevertheless act in concert, the standpoints of the different members of the collective should be discussed and weighed. To be legitimate, authority in firms should thus be exercised democratically, namely those under authority, i.e., employees of all levels in the hierarchy, should somehow take part in the decisions (strategic and operational) the firm needs to make, or elect the people who are to make them. That is, the procedures used to take decisions and generate the authoritative directives should be democratic - this is the proceduralist legitimation of authority (Christiano 2004).

Firms are composed of a complex set of members and groups of members (shareholders, chief executives, departments with divergent functional goals, etc.) with different aims. Conflicts of different sorts inescapably arise because the aims of all groups cannot be simultaneously realized. This makes firms political entities. Political power stands at the crossroad of the two axes mentioned above: the horizontal axis composed of those involved in working together and the vertical axis composed by the authority relationship. When "managerial authority is best regarded not as the authority of a principal over an agent but rather as authority that facilitates mutually beneficial cooperation among employees with divergent aims $[\ldots]$ there is a presumption that managerial authority should be democratically exercised by the employees" (McMahon 1994: iii). According to McMahon (1994: 133), the legitimation of authority thus requires a kind of workplace democracy defined as: "I regard democracy as 
reflexive authority, a way of exercising authority in which those who are subject to authority collectively determine the authoritative directives that will guide them".

\subsection{Legitimating authority: implications for firm governance}

If "reflexive authority" is what best legitimates C-authority, managers must be formally considered as serving not a principal (shareholders) but rather the employees themselves (bearing in mind that the latter are composed of very heterogeneous groups). This implies a radical reshaping of corporate law and of the statutes that regulate the governance of business firms. McMahon (1994) advances three ways - not exclusive of each other - in which corporate law could establish the conditions for workplace democracy as reflexive authority: 1) by having employees participate in boardrooms on an equal footing with shareholders, 2) by creating the conditions for making management accountable to employees, 3) by having employees elect the directors and/or managers. These alternative institutional arrangements would give employees, to a greater or lesser extent, pre-emptive reasons for complying.

Note that most of these suggestions - the end of shareholder dominance, employees' representation in boardrooms, and managers' accountability to employees - are advocated since long by progressive law scholars (Bodie 2017; Greenfield 1998) and are now discussed in many countries who engaged in a revision of the corporate statute of firms (e.g, France, the UK, Italy). The German codetermination (Mitbestimmung) model and its Scandinavian counterparts are closely scrutinized with the aim of envisaging the progressive establishment of differentiated versions of this model in all European countries. The European Union would then have, to reinforce its social model, a democratic "European firm governance model". One must be aware that it is critical that the participation of employees in board-level bodies - who must hold at least one third of the seats for their participation to be effective - be complemented by plantlevel works councils. The industrial relations literature shows that the role and national culture of trade-unions is a crucial building block of the well-functioning of this kind of institutional settings.

Of course, codetermination does not make the conflicts of interests disappear. Rather, and although the concept of C-authority focuses on cooperation, codetermination is a way of putting conflict at the center of the firm governance system; it is based on a conflictual rather than consensual conception of democracy. Co-determination, which includes work councils, is a sophisticated and advanced way to manage consent, conflict and control in work organizations. The importance of work councils should not be overlooked: experience shows that the most crucial factor for the success of employee participation is that it is not driven by top-down processes but emerges from the collectives of work. A basic requirement is that employees 
understand how their work contributes functionally to joint production within and across units. Based on this knowledge, they, or their representatives, can decide on which and how binding decision are to be made (Le Gall, 2011). Whilst this implies a weakening of the command and control structures, it does not eliminate managerial authority - in whose decision employees now participate.

As for economic efficiency, the benefits and shortcomings of codetermination are difficult to capture. Overall, the empirical evidence collected on the German experience concludes that the effect on productivity and other economic variables is non-significant or positive but often small; it may at least be safely assumed that codetermination does not impair economic efficiency (Fitzroy and Kraft 2005; Mueller 2015).

\subsection{Digital platform work: firms without authority?}

Digital Platforms Work (DPW hereafter, also termed the "uberization" of work), like crowdwork and on-demand work, raises the serious question of whether authority is involved. As patent in the Alchian and Demsetz' quote in the introduction, the way the employment relationship is conceived is constitutively associated to that of the nature of the firm. For agency theory, employee-free firms are perfectly possible since there is no substantial difference between an employment contract and a contract for services, which logically leads to conceive firms as authority-free. In contrast, our argument is that C-authority is constitutively related to seeing work and the firm as collective endeavors.

The much reiterated claim of digital platforms is that the application matches the supply (e.g. Uber drivers) and the demand (clients) of work and does nothing more, which is far from being correct:

1) Platforms are not, like markets, mere intermediaries between demand and supply: they actually regulate the labor market (setting prices, deciding which and how information about workers and clients is collected and displayed, etc.).

2) Although there are no human managers/supervisors, the app performs actual management functions (assigning workers to clients, supervising workers and assessing their performance, etc.)

3) On-line platforms do not hire for jobs, they contract for specific, entirely specified tasks (Davis 2016). Economists would say that these are instances of complete contracts. Now the incompleteness of employment contracts is the major ground for authority (Coase, 1937; Simon 1951; Rajan and Zingales, 1998).

4) A wide retaylorization of work is taking place with the crucial difference that in DPW tasks are not technically nor organizationally interdependent; workers perform their activity in total isolation, there is no collective of work nor any shared goals. The application

\footnotetext{
DINÂMIA'CET - IUL, Centro de Estudos sobre a Mudança Socioeconómica e o Território do Instituto Universitário de Lisboa (ISCTE-IUL)

Sala 2W4 - D | ISCTE-IUL - Av. das Forças Armadas 1649-026 Lisboa, PORTUGAL

Tel. (+351) 210464031 - Extensão 293101 | E-mail: dinamia@iscte-iul.pt | www.dinamiacet.iscte-iul.pt
} 
distributes work among an indistinct crowd of individuals, with whom and between whom there are no personal relationships.

Features 2, 3 and 4 above make it clear that C-authority is notoriously absent from DPW. For authority is by essence interpersonal, even when it is exercised through rules and procedures rather than through persons. "The relation between employer and employee is no longer a market relation but an authority relation" (Arrow 1974: 64), a relationship in which the parties have mutual relational duties to one another. We have also seen that $\mathrm{C}$-authority involves the relation between an individual and a collective; yet, there is no collective of work and therefore no need for authority in DPW - there is no need for cooperation since there is no interdependence between activities, no need to mitigate free riding since it is workers who decide when and whether to work, no common/collective goal to be pursued and consequently no need for commonly shared behavioral norms. That is, there is no place for verticality workers behave according to their own reasons without being required to refer to preemptive reasons. This depersonalization is patent in the fact that there is no human communication in DPW, either with the firm/platform or with other workers, something which is reported by workers as being highly detrimental to their psychological well-being (Berg 2016).

Firms as initially conceived by agency theory were ultimately abstract fictions, as agency theorists themselves have since recognized. But it is as if technology has made the fiction possibly become true: digital platform firms are nexuses of impersonal and casual contracts; there is no teamwork, no subordination to a managerial hierarchy, no need for cooperation - technologically mediated coordination suffices. Digital economy, originally expected to be a "sharing economy" is transforming part of the world of work into a set of isolated workers, thus threatening to promote homo economicus' calculative and egocentric behavior, with no need for sympathy and the dissolution of work collectives and employment relationships into market exchanges.

However, DP workers are no doubt working for the platform since the latter deducts a (substantial) fee from their work and, above all, since it exerts considerable control upon their performance, their access to work and their exclusion from it. In other words, the platform does not exercise authority on workers but it has extensive power over them; the distinction between authority and coercive power proves here particularly relevant. DPW may mean that substantive work as we define it is deteriorating but it does not mean that firms cease to be political entities that use power to manage and design work. DP workers cannot be considered standard employees but they cannot be considered independent contractors either. 
The fact that there is no C-authority in DPW excludes workers from workplace democracy as conceived here; since there are no collective of work and no managerial hierarchy, it makes no sense to elect (unknown) representatives to participate on boards, let alone on work councils. But DP workers can exercise their voice through other means, by creating communities of professionals, within unions or not (see examples of such endeavors in Berg 2016), in order to influence and negotiate the regulation of DPW (see feature 1 above). To sum up, digital platforms are not authority-based firms because DP workers do not cooperate together to produce a collective output, but they do control workers who should then be protected by labor and social protection laws as well as be provided with collective bargaining rights. The scope of labor law should go beyond that of standard employment (Supiot, 2015).

\section{CONCLUDING REMARKS}

The aims of the present paper were to scrutinize the standard economic theory of work and the agency theory of the firm to call attention to the substantive features of work and firms dismissed in the formal approach to economics. By jointly analyzing theories of work and of the firm, which have been maintained separate in the economics literature, we hope to have enhanced our explanatory and normative power.

Section Two upholds that mainstream economics understands work as an isolated instrumental activity while section Three contends that the analytical framework of agency theory can only account for E-authority (authority based on Expertise), which is a nonsubordinating authority. By contrast, the core components of the substantive conceptions of work and of the firm advanced here is the meaningfulness and collective character of work and the firm, which is largely grounded on subordinating authority. Our analytical account of the phenomenon of authority builds on McMahon (1994) who understands managerial authority (labelled C-authority for "cooperative authority") as justified by the fact that it facilitates mutually beneficial cooperation among individuals with divergent aims and beliefs. Authority directives are considered preemptive reasons for acting and complied with because complying is seen as benefitting each and all members of the collective. This is not to deny that obedience in work organizations also result from coercive power, but an organization could not function without authority, i.e., an accepted rather than coercive form of power.

As referred, our basic argument is that firms are collectives of persons, a "system of cooperative services of persons" directed by $\mathrm{C}$-authority rather than just the "sum of services of individuals" (Barnard 1938: 110) related by incentive contracts. The collective dimension of

\footnotetext{
DINÂMIA'CET - IUL, Centro de Estudos sobre a Mudança Socioeconómica e o Território

do Instituto Universitário de Lisboa (ISCTE-IUL)

Sala 2W4 - D | ISCTE-IUL - Av. das Forças Armadas

1649-026 Lisboa, PORTUGAL

Tel. (+351) 210464031 - Extensão 293101 | E-mail: dinamia@iscte-iul.pt | www.dinamiacet.iscte-iul.pt
} 
work and the firm requires, and is composed of, interpersonal interactions. And this is what is ultimately discarded by formal economics: the fact that interpersonal interactions always activate the human capacity of sympathy (advanced by Adam Smith and revisited by Sugden, 2005). The meaningfulness of work and the cooperative behavior associated with C-authority are explained by the affective and normative abilities of "sympathetic" humans; the individualistic ontological framework of rational choice theory cannot give a full account of such phenomena.

Nowadays, the control, remuneration and evaluation of workers is supported by quantified targets, which suggests that firms are becoming blind to what distinguishes the work of humans from that of machines. It is as if our societies are ignoring that human work is the only real source of economic value. (As Hannah Arendt warned, when the human is reduced to the non-human, everything becomes possible). The quantified pervading managerial practices the "governance by numbers" denounced by Supiot (2015) - are threatening to transform firms into psychopathic institutional environments (Brons, 2017). These phenomena are largely influenced by the normative impact exerted in the real world by economics formalism (Goshal, 2005).

"Only one task now remains; and that is to see whether the concept of a firm which has been developed fits in with that existing in the real world" (Coase, 1937:403). In what concerns agency theory, the uberization of work is close to make formal economics and Polany's market system nightmare becoming true. (But if technological evolution is irreversible, neo-liberalism is not (Supiot, 2015)). In analytical terms, we are convinced that our substantive conception of work and authority-based firm do correspond to the real facts. But our normative approach, that firms are to be governed by "reflexive authority", is far from reality. Yet, it could be one of the ways to free ourselves from dangerous abstractions and formalisms and propose a political project that would prioritize work over the market. 


\section{REFERENCES}

ALCHIAN, A. and Demsetz, H. (1972). 'Production, information costs and economic organization'. American Economic Review, LXII(2): 777-795.

ARMOUR, J. (2005). 'The proprietary foundations of corporate law'. ESCR Working Paper $n^{o}$ 299, Center for Business Research, University of Cambridge.

ARROW, K. (1974). The limits of organization. New-York: Norton and Company.

BARNARD, C. (1938). The functions of the executive. Cambridge: Harvard University Press.

BARSADE, S. (2002). The Ripple Effect: Emotional contagion and its influence on group behavior, Administrative Science Quarterly, 44: 644-675.

BERG, J. (2016). 'Income security in the on-demand economy: Findings and policy lessons from a survey of crowdworkers'. Comparative Law and Policy Journal, 37(3): 1-27.

BERG, N. and Gigerenzer, G. (2010) "As-if behavioral economics: Neoclassical economics in disguise?, " History of Economic Ideas 18(1): 133-166.

BODIE, M. (2017). 'Employment as fiduciary relationship'. Georgetown Law Journal, 2016: 169.

BODIE, M. (2012). 'The post-revolutionary period in corporate law'. Seattle University Law Review, 35: 1033-1059.

BOLTON, P. and Dewatripont, M. (2013). 'Authority in organizations: A survey'. in Gibbons, R. and Roberts, J. (eds), Handbook of Organizational Economics. Princeton University Press, pp. 342-372.

BOWLES, S. (2004). Microeconomics - Behavior, institutions and evolution. New-York: Princeton University Press.

BRONS, L. (2017) : The Hegemony of Psychopathy, Santa Barbara: Brainstorm Books.

\footnotetext{
DINÂMIA'CET - IUL, Centro de Estudos sobre a Mudança Socioeconómica e o Território do Instituto Universitário de Lisboa (ISCTE-IUL)$$
\text { Sala 2W4 - D | ISCTE-IUL - Av. das Forças Armadas }
$$$$
\text { 1649-026 Lisboa, PORTUGAL }
$$ 
CHARNESS G and Kuhn P (2011) Lab labor: what can labor economists learn from the lab? In: Ashenfelter O and Card D (eds) Handbook of Labor Economics. Amsterdam: North Holland.

CLARK, R. (1985): “Agency costs versus fiduciary duties”, in Pratt, J. and Zeckhauser, R. (ed.) Principals and Agents, Boston: Harvard Business School Press.

CRAWSHAW, J., Cropanzano, R., Bell, C., Nadisic, T. (2013), 'Organizational justice: New insights from behavioural ethics'. Human Relations, 66(7): 885-904.

CHRISTIANO, T. (2004). 'The authority of democracy'. Journal of Political Philosophy, 12(3): 266-290.

CUSHEN, J. and Thompson, P. (2016): Financialization and value: why labour and the labour process still matter, Work, Employment and Society, 30(2): 352-365.

DAVIS, G. (2016). 'What might replace the modern corporation? Uberization and the web page enterprise'. Seattle University Law Review, 39: 501-515.

DECI, E., Olafsen, A., Ryan R. (2017): Self-Determination Theory in work organizations, Annual Review of Organizational Psychology and Behavior, 4: 19-43.

DUSKA, R. (1992) "Why be a loyal agent? A systemic ethical analysis", in Freeman E. and Bowie N. (ed.), Ethics and Agency Theory, New-York: Oxford University Press.

FITZROY, F. and Kraft, K. (2005). 'Codetermination, efficiency and productivity'. British Journal of Industrial Relations, 43(2): 233-247.

GOSHAL, S. (2005) "Bad management theories are destroying good management practices," Academy of management Learning and Education 4(1): 75-91.

GREENFIELD, K. (1998). 'The place of workers in corporate law'. Boston College Law Review, 39(2): 283-327.

GREGORIC, Aleksandra and Rapp, Marc Steffen and Sinani, Evis, Board-Level Employee Representation and Firms' Responses to Crisis (January 3, 2017). Available at SSRN: https://ssrn.com/abstract=3012999 or http://dx.doi.org/10.2139/ssrn.3012999

DINÂMIA'CET - IUL, Centro de Estudos sobre a Mudança Socioeconómica e o Território do Instituto Universitário de Lisboa (ISCTE-IUL)

Sala 2W4 - D | ISCTE-IUL - Av. das Forças Armadas 1649-026 Lisboa, PORTUGAL 
HART, O. (1989). 'An economist's perspective on the theory of the firm'. Columbia Law Review, 89 (7): 1757-1774.

JENSEN, M. and Meckling H. (1976). 'Theory of the firm: managerial behavior, agency costs and ownership structure'. Journal of Financial Economics, 3 (4), 305-60.

LE GALL, J-M. (2011) L'entreprise irréprochable, Paris: Desclée de Brower.

LOPES, H. (2018). 'The moral dimensions of the employment relationship - Institutional implications'. Journal of Institutional Economics, published online 02 May.

LOPES, H (2011) Why do people work? Individual wants versus common goods. Journal of Economic Issues, 45: 57-74.

LOPES, Helena (2018): The moral dimensions of the employment relationship - Institutional implications, Journal of Institutional Economics, DOI: https://doi.org/10.1017/S1744137417000170, forthcoming.

MARSDEN, D (2016): Norms of exchange and the socio-economics of labour markets, in Kaufman, B. (ed), Labor Market Models, Chicago: Stanford University Press, pp. 2-40.

MCMAHON, C. (1994; reed. 2017). Authority and democracy. Princeton: Princeton University Press.

MUELLER, S. (2015). 'Works councils and labor productivity: looking beyond the mean'. British Journal of Industrial Relations, 53(2): 308-325.

NETTERSTROM, B., Conrad, N., Bech, P., Fink, P., Olsen, O., Rugulies, R. and Stansfeld, S. (2008) "The relation between work-related psychosocial factors and depression," Epidemiological Review 30: 118-132.

OOSTERHOUT, J. (2007). 'Authority and democracy in corporate governance?'. Journal of Business Ethics, 71: 359-370.

DINÂMIA'CET - IUL, Centro de Estudos sobre a Mudança Socioeconómica e o Território do Instituto Universitário de Lisboa (ISCTE-IUL)

Sala 2W4 - D | ISCTE-IUL - Av. das Forças Armadas 1649-026 Lisboa, PORTUGAL 
POLANYI, K. (1957): The economy as an instituted process, in Polanyi, Arensberg and Pearson (ed), Trade and Markets in the Early Empires, Chicago: Gateway Edition, pp. 243-270.

PARETO, V. (1896): Cours d'Économie Politique, Lausanne: Rouge.

RAJAN AND ZINGALES (1998): Power in a theory of the firm, The Quarterly Journal of Economics, 113(2): 387-432.

RAZ, J. (2006). 'The problem of authority'. Minnesota Law Review, 90: 1003-1044.

RAZ, Joseph, (1986), The Morality of Freedom, Oxford: Oxford University Press.

REBITZER JB and Taylor LJ (2011) Extrinsic rewards and intrinsic motives: standard and behavioural approaches to agency and labor markets. In: Ashenfelter O and Card D (eds) Handbook of Labor Economics. Amsterdam: North Holland.

ROSSO BD, Dekas KH and Wrzesniewski A (2010) On the meaning of work: a theoretical integration and review. Research in Organizational Behavior, 30: 91-127.

SIMON, H. (1951). 'A formal theory of the employment relationship'. Econometrica, 19(3): 293-305.

STEGER MF, Dik BJ and Duffy RD (2012) Measuring meaningful work. Journal of Career Assessment, 20(3): 322-337.

SUGDEN, R. (2015): Team reasoning and intentional cooperation for mutual benefit, Journal of Social Ontology, 1(1): 143-166.

SUGDEN, R. (2005): Fellow-feeling, in Gui and Sugden, Economics and Social Interactions, Cambridge: Cambridge University Press.

SUPIOT, A. (2015): La Gouvernance para les Nombres, Nantes: Fayard.

DINÂMIA'CET - IUL, Centro de Estudos sobre a Mudança Socioeconómica e o Território do Instituto Universitário de Lisboa (ISCTE-IUL)

Sala 2W4 - D | ISCTE-IUL - Av. das Forças Armadas 1649-026 Lisboa, PORTUGAL 
THEORELL T, Hammarström A, Aronsson G, Bendz LT, Grape T, Hogstedt C, Marteinsdottir I, Skoog I and Hall C (2015) A systematic review including meta-analysis of work environment and depressive symptoms. BMC Public Health, 15: 738-752.

TYLER, T. and Lind, A. (1992). 'A relational model of authority in groups'. Advances in Experimental Social Psychology, 25: 115-191.

VAN DEN STEEN, E. (2010). 'Interpersonal authority in a theory of the firm'. American Economic Review, 100: 466:490.

WEBER, M. (1922). Economy and society. Berkeley: University of California Press.

WILLIAMSON, Oliver (1983/1975). Markets and hierarchies. New-York: The Free Press.

WILLIAMSON, Oliver (1980). 'The organization of work'. Journal of Economic Behavior and Organization, 1: 5-38.

ZAKI, J. and Ochsner, K. (2012): The neuroscience of empathy, Nature Neuroscience, 15(5): 675-680.

DINÂMIA'CET - IUL, Centro de Estudos sobre a Mudança Socioeconómica e o Território do Instituto Universitário de Lisboa (ISCTE-IUL) 